\title{
IMPACT OF THE NATURAL MORTALITY (M) VARIABILITY ON THE EVALUATION OF THE EXPLOITABLE STOCK OF SARDINE, SARDINA PILCHARDUS (ACTINOPTERYGII: CLUPEIFORMES: CLUPEIDAE) OF THE CENTRAL REGION OF THE ALGERIAN COAST
}

\author{
Ahmed BOUAZIZ*, Fedja KERZABI, and Boualem BRAHMI \\ Fisheries and Aquaculture Department, ENSSMAL, Algiers, Algeria
}

\begin{abstract}
Bouaziz A., Kerzabi F., Brahmi B. 2014. Impact of the natural mortality $(M)$ variability on the evaluation of the exploitable stock of sardine, Sardina pilchardus (Actinopterygii: Clupeiformes: Clupeidae) of the central region of the Algerian coast. Acta Ichthyol. Piscat. 44 (2): 87-97.
\end{abstract}

\begin{abstract}
Background. The landings of sardine, Sardina pilchardus (Walbaum, 1792), captured by purse seiners in the central region of the Algerian coast, Mediterranean Sea have been decreasing over the last decade. The catch was $22580.28 \mathrm{t}$ in 2001 but fell to $5600 \mathrm{t}$ in 2011 . To better understand the above decline, we found it useful to evaluate the impact of the change of the natural mortality $(M)$ on the estimation of the exploitable stock of this species. Materials and methods. To study the exploitation of sardine, a total of 4476 individuals of both sexes were sampled monthly in 2010. All sardines were taken from the landings of purse seiners operating in the central region of the Algerian coast between Tenes and Bejaia. The study of biological parameters and mortality were undertaken by the software recommended by FAO (FISAT II 1.2, FISHPARM 3.0 T, and the New VONBIT for Excel). Finally, VIT Software 1.2 was used for the evaluation of virtual population analysis (VPA), yield and biomass per recruit. Results. The analysis of yield and biomass per recruit using two approaches for estimating the natural mortality, namely the method of Pauly and that of Djabali et al., shows that the state of the sardine stock in the central region of the Algerian coast changed totally from a state of not overfished and not overfishing to a state of overfished and overfishing. The choice between these two scenarios, for which is important to advise and guide the management of the fisheries focuses on the case of overfishing and overfished. This choice is motivated by the geographical origin of the biological material used for the equation of natural mortality.

Conclusion. The reduction of the current fishing effort factor $\left(F_{\mathrm{C}}=1\right)$ to the factor of fishing mortality rate at which the marginal yield-per-recruit constitutes only $10 \%$ of the marginal yield-per-recruit on the unexploited stock $\left(F_{0.1}=0.23\right)$ would permit in the long term, a maximum sustainable production of sardines of the central region of the Algerian coast which will increase from 5600 to $5999.7 \mathrm{t}$, while ensuring the renewal of its stock in sea which will rise from 3987 to 12487.8 t. Finally, it would be interesting to extend this study for all major pelagic species captured along the Algerian coasts.
\end{abstract}

Keywords: Exploitation, $F_{0.1}$, overfished, overfishing

\section{INTRODUCTION}

In the central region of the Algerian coast, located between Tenes $\left(36^{\circ} 30^{\prime} \mathrm{N}\right.$ and $\left.1^{\circ} 20^{\prime} \mathrm{E}\right)$ in the west and Bejaia $\left(36^{\circ} 45^{\prime} \mathrm{N}\right.$ and $\left.5^{\circ} 06^{\prime} \mathrm{E}\right)$ in the east (Fig. 1), the landings of sardine, Sardina pilchardus (Walbaum, 1792), captured by the purse seiners have decreased over the last decade. The landings which were $22580.28 \mathrm{t}$ in 2001 fell to $5600 \mathrm{t}$ in 2011 (Anonymous 2006, 2012a). To better understand this decline, we found it useful to undertake a study of its operating condition by adjusting its production to the factor of fishing mortality rate at which the marginal yield-per-recruit is only 10 percent of the marginal yield-per-recruit on the unexploited stock $\left(F_{0.1}\right)$. This value, also called $F$ target is part of Target Reference
Points (TRP). It allows the best possible catch, while promoting the conservation of the stock (Anonymous 1996, 2012b, Caddy 2009). Moreover, it is interesting to note that the yield and biomass per recruit and the spawning biomass per recruit are highly vulnerable to changes in natural mortality. Therefore, we found it useful to take two different approaches for the evaluation of the mortality $(M)$, i.e., the equation of Pauly (1980) and that of Djabali et al. (1994). The use of these two approaches permitted to detect a bias in the direct evaluation of $M$.

Finally, the ultimate goal of this study was to draw attention to the relevance of the use of $M$ for the estimation of the state of the sardine stock. This parameter is indispensable for a rational management of fisheries,

\footnotetext{
${ }^{*}$ Correspondence: Dr Ahmed BOUAZIZ, ENSSMAL, B.P. 19 Bois des Cars, Dély-Ibrahim, Alger, Algérie, phone: +21321917774, fax: +21321917791, e-mail: (AB)
} abouaziz@yahoo.fr, (FK) kerzabi_fedja@yahoo.fr, (BB)bab_as@yahoo.fr. 
which is the only guarantee for a sustainable and responsible exploitation of the fishery resource.

\section{MATERIAL AND METHODS}

It is important to know whether sardines (Sardina pilchardus) from the Algerian coast belong to one or more stocks. Trying to answer this question, we selected a single meristic character-namely the number of vertebrae. Others characters, such as the number of rays of different fins or the number of gill rakers, especially those on the lower part of the first gill arch, were excluded because of their lower discriminative value in relation to different exploitable stocks of sardine along the Algerian coast (Bouaziz 2007).

During June 2010, five sets of samples consisting of 90, 84, 55, 89, and 323 sardines, Sardina pilchardus, were simultaneously collected from the vicinity of five Algerian ports: Arzew, Tenes, Algiers, Bejaia, and Skikda, respectively (Fig. 1) and their mean number of vertebrae was studied. The vertebrae were numbered starting behind the occipital condyle towards the urostyle inclusive.

To study the exploitation of sardines, 4476 fish of both sexes were sampled monthly in 2010. Their sizes ranged from 7 to $22.9 \mathrm{~cm}$. All the sardines were taken from the landings of purse seiners operating in the central region of the Algerian coast between Tenes and Bejaia.

The age determination was carried out by the method of Bhattacharya witch the application protocol was slightly modified by Gayanilo et al. (2005). This choice is motivated by the recommendations of the working group DYNPOP of the CIESM (Abella et al. 1995, Aldebert and Recasens 1995, Alemany and Oliver 1995, Campana 2001, Bouaziz 2006).

Concerning the study of linear growth parameters of the von Bertalanffy equation, we used the FISAT II 1.2.0 (Gayanilo et al. 2005), FISHPARM 3.0 T (Saila et al. 1988) and the New VONBIT for Excel (Stamatopoulos unpublished*).

The GFCM Working Group (Anonymous 2012b) recommends the computation of the performance index,

$$
\varnothing^{\prime}=\log _{10} K+2 \log _{10} L_{\infty}
$$

where $K$ (curvature parameter of the von Bertalanffy growth function) and $L_{\infty}$ (asymptotic length) are the von Bertalanffy growth function parameters (Pauly and Munro 1984), to verify the accuracy of the parameters of linear growth of the von Bertalanffy equation. To do this, we simply compared the value of $\varnothing^{\prime}$ obtained to that calculated in the database of FishBase.

For the study of length-weight relation, 1165 pairs of values total length (TL)-total weight $(W)$ of sizes ranging from $7 \mathrm{~cm}$ to $22.9 \mathrm{~cm}$ were adjusted by the equation

$$
W=a \mathrm{TL}^{b}
$$

As already recommended by Bouaziz et al. (1998) and Froese et al. (2011), the type of allometry is confirmed or otherwise by the $t$-test based on the comparison between a calculated slope $(b)$ and a theoretical slope (3).

The natural mortality coefficient is one of the most

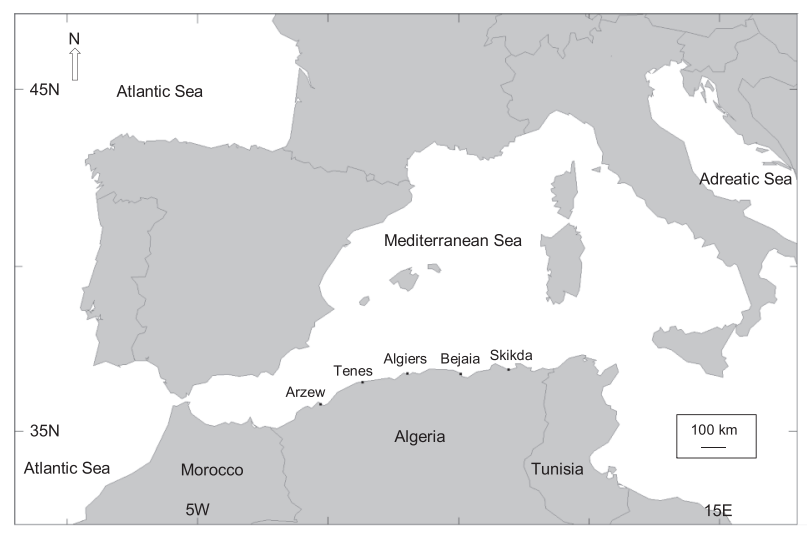

Fig. 1. Coast of Algeria showing fisheries ports associated with the sampling sites of sardine, Sardina pilchardus

difficult parameters to estimate. However, a value as accurate as possible of $M$ is necessary to implement the most usual models of stocks management (Pauly 1984). For its evaluation, we found it useful to use two equations as follows:

- The equation of Pauly (1980):

$\log M=-0.0066 \times 0.279 \times \log L_{\infty}+0.6543 \times \log K+$ $0.4634 \times \log T$

where $T$ is temperature.

- The equation of Djabali et al. (1994):

$\log _{10} M=0.0278-0.1172 \times \log _{10} L_{\infty}+0.5092 \times \log _{10} K$

This approach allows highlighting of the impact of $M$ on the state of the sardine stock in the central region of the Algerian coast.

For the evaluation of total mortality $(Z)$, the method of Pauly (1990), based on catch curves according to lengths, was chosen, because it fits better on short-lived species such the sardine. In addition, it has the advantage of circumventing the difficulties associated with the evaluation of ages (Pauly 1990).

As Sparre and Venema (1996), observations are excluded from the linearized regression curve of catches. These are the first size classes that form the ascending part of the curve. These fish are not yet fully recruited to the fishery. Larger size classes are also excluded for the following reasons:

- Low numbers of samples,

- As we approach $L_{\infty}$ the relation between age and length becomes uncertain.

The fact that the percentage of mature individuals by size class is an essential input in estimating spawning biomass makes its determination necessary. To do this, 1035 sardines were analysed. This sampling was carried out during the spawning period which runs from November to March.

Finally, following the recommendations of Kirkegaard et al. (2008), Anonymous (2009), Caddy (2009), and Rätz et al. (2010), VIT Software 1.2*, was used for the evaluation of virtual population analysis (VPA), yield and biomass per

\footnotetext{
${ }^{*}$ Stamatopoulos C. New VONBIT for Excel. Estimation of von Bertalanffy growth parameters from age-length data. Fisheries Resources Monitoring and Assessment Lamans.

${ }^{*}$ Lleonart J., Salat J. VIT (version 1.2) Software for fishery analysis. User's manual.
} 
recruit. This software designed for Mediterranean fisheries, has the advantage of working with pseudo-cohorts, that is to say, it only requires knowledge of the catches in one year instead of a long historical series of ten years.

\section{RESULTS}

Vertebral count. Application of ANOVA has shown that the vertebral mean $(m)$ values for individuals caught in the central region of the Algerian coast (Tenes, Algiers, and Bejaia), were: $51.23 \pm 0.13,51.18 \pm 0.16$, and $51.21 \pm 0.13$, respectively (Table 1 ) and they did not vary significantly: the value of $F=0.105$ was much lower than the critical value for a significance level of $\alpha=0.05, F_{2 / 225}=3$ ). The comparison of the vertebral mean of all of these fish from central region $(m=51.21 \pm 0.08, n=228)$ to those individuals captured in Arzew $(m=50.7 \pm 0.14, n=90)$ and Skikda $(m=51.55 \pm 0.07, n=323)$ revealed a gradual and significant increase of the mean value from west to east: $F=65.36$ was much larger than the critical value for a level of significance of $\alpha=0.05, F_{2 / 638}=3$ (Table 2).

Calculation of biological parameters and mortality. The Bhattacharya method splits the sample sardine of both sexes into four cohorts with lengths oscillating around 10.31, 14.50, 17.76, and $21.79 \mathrm{~cm}$. Two-year old sardines were the most common in the catches $(66.79 \%)$, followed by 1 year olds $(29.89 \%)$. The minimum catch rate $(0.18 \%)$ was observed for individuals of 4 years of age (Table 3).

Frequency distribution of vertebral number of sardine, Sardina pilchardus,

Table 1 in the central part of Algeria (between Tenes and Bejaia)

\begin{tabular}{|c|c|c|c|c|}
\hline $\begin{array}{l}\text { Number } \\
\text { of the vertebrae }\end{array}$ & $\begin{array}{c}\text { Tenes } \\
n\end{array}$ & $\begin{array}{c}\text { Algiers } \\
n\end{array}$ & $\begin{array}{c}\text { Bejaia } \\
n\end{array}$ & Total \\
\hline 50 & 9 & 5 & 11 & 25 \\
\hline 51 & 47 & 36 & 48 & 131 \\
\hline 52 & 28 & 13 & 30 & 71 \\
\hline 53 & 0 & 1 & 0 & 1 \\
\hline Total & 84 & 55 & 89 & 228 \\
\hline $\begin{array}{l}\text { Vertebral mean } \\
(\alpha=5 \%)\end{array}$ & $51.23 \pm 0.13$ & $51.18 \pm 0.16$ & $51.21 \pm 0.14$ & \\
\hline
\end{tabular}

$n=$ number of specimens.

Table 2

Frequency distribution of vertebral number of sardine, Sardina pilchardus, in the Algerian coast

\begin{tabular}{lcccr}
\hline $\begin{array}{l}\text { Number } \\
\text { of the vertebrae }\end{array}$ & $\begin{array}{c}\text { West coast } \\
\text { (Arzew) }\end{array}$ & Central coast & $\begin{array}{c}\text { East coast } \\
\text { (Skikda) }\end{array}$ & Total \\
\hline 49 & 4 & 0 & 0 & 4 \\
50 & 27 & 25 & 15 & 67 \\
51 & 51 & 131 & 125 & 307 \\
52 & 8 & 71 & 172 & 251 \\
53 & 0 & 1 & 11 & 641 \\
\hline Total & 90 & 228 & 323 & \\
\hline Vertebral mean & $50.7 \pm 0.14$ & $51.21 \pm 0.08$ & $51.55 \pm 0.07$ & \\
$(\alpha=5 \%)$ & & &
\end{tabular}

Decomposition of composite distribution using Bhattacharya's method (FISAT II 1.2.0) of sardine, Sardina pilchardus, in the central region of the Algerian coast

\begin{tabular}{|c|c|c|c|c|c|}
\hline \multirow{2}{*}{ Age [year] } & \multirow{2}{*}{$\mathrm{CM}[\mathrm{cm}]$} & \multicolumn{2}{|c|}{ Population } & \multirow{2}{*}{ Separation index } & \multirow{2}{*}{ Growth rate } \\
\hline & & $n$ & {$[\%]$} & & \\
\hline 1 & $10.31 \pm 1.7$ & 991 & 29.89 & - & 4.19 \\
\hline 2 & $14.50 \pm 1.13$ & 2214 & 66.79 & 2.96 & 3.26 \\
\hline 3 & $17.76 \pm 1.24$ & 104 & 3.14 & 2.75 & 4.03 \\
\hline 4 & $21.79 \pm 0.65$ & 6 & 0.18 & 4.26 & \\
\hline
\end{tabular}

$\mathrm{CM}=$ computed mean \pm standard deviation; $n=$ number of fish; Growth rate $=(\mathrm{TL}+1)-\mathrm{TL}$. 
The results of the parameters of linear growth, $\varnothing^{\prime}$, mortalities $(Z, M$, and $F)$ and the percentage of mature individuals, both sexes, are shown in Table 4 and Figs. 2-4.

Catch-number and catch-weight. The analysis of Table 5 shows that regardless of the value of $M$, the maximum catch in number (64.1 million) and in weight (1392 $\mathrm{t}=24.85 \%$ of total production (catch) was represented by the class size of $14.5 \mathrm{~cm}$. The catch mean length and the catch mean age were $12.8 \mathrm{~cm}$ and 1.6 years, respectively. Analysis of the biomass by the VPA. The biomass balance $(D)$, was evaluated for $M=0.91 \mathrm{yr}^{-1}$ (Pauly 1980), as $10217.66 \mathrm{t}$. It is mainly due to growth, representing $8170.54 \mathrm{t}(79.96 \%)$. It is well above the recruitment, which is about $2047.11 \mathrm{t}(20.04 \%)$. Losses caused by natural mortality, estimated at $4617.66 \mathrm{t}(45.19 \%)$ are lower than the fishing mortality estimated at $5600 \mathrm{t}$ (54.81\%).
Finally, the critical age and the critical length of the virgin stock $\left(B_{0}\right)$ were 1.8 years and $14 \mathrm{~cm}$, respectively.

For $M=0.49 \mathrm{yr}^{-1}$ (Djabali et al. 1994), the biomass balance was estimated as $7553.53 \mathrm{t}$ in which major gains are due to the growth $(6233.92 \mathrm{t}, 82.53 \%)$ followed by recruitment that represents only $1319.61 \mathrm{t}(17.47 \%)$. Losses caused by natural mortality (1953.53 t, 25.86\%) are much lower than those generated by the fishing mortality (5600 t; $74.14 \%$ ). In the absence of fishing, the critical length and the critical age were $18 \mathrm{~cm}$ and 2.8 years, respectively.

Biomass and yield per recruit. For $M=0.91 \mathrm{yr}^{-1}$ (Pauly 1980), the mean biomass of the sardine was estimated at $5074.35 \mathrm{t}$, of which spawning stock biomass (SSB) was $2189.22 \mathrm{t}$, or $43.14 \%$ of the stock. The yield (production) per current recruit $\left(Y_{\mathrm{C}} \cdot R^{-1}=6.688 \mathrm{~g}\right.$, factor of current effort fishing

Data needed for the calculation of the exploitation according to the length of sardine,

Table 4

Sardina pilchardus, in the central region of the Algerian coast

\begin{tabular}{|c|c|c|c|}
\hline ML & $n$ & MI & Parameter \\
\hline 7.5 & 93 & 0 & von Bertalanffy's equation \\
\hline 8.5 & 203 & 0 & $L_{t}=25.12\left(1-\mathrm{e}^{-0.45(t+0.0028)}\right)($ New VONBIT for Excel $)$ \\
\hline 9.5 & 332 & 0 & (Figs. 2, 3) \\
\hline 10.5 & 363 & 0.08 & $L_{t}=25.20\left(1-\mathrm{e}^{-0.44(t+0.0028)}\right)($ FISHPARM $3.0 \mathrm{~T})$ \\
\hline 11.5 & 819 & 0.33 & $L_{t}=25.28\left(1-\mathrm{e}^{-0.45 t}\right)($ FISAT II, 1.2.0) \\
\hline 12.5 & 645 & 0.54 & $\varnothing^{\prime}=2.45$ \\
\hline 14.5 & 900 & 0.87 & Allometry equation (FISHPARM $3.0 \mathrm{~T}$ ) \\
\hline 15.5 & 521 & 0.95 & $W=0.00695 \cdot L^{3.013}$ \\
\hline 16.5 & 173 & 0.99 & Mortality estimation (FISAT II 1.2.0) \\
\hline 17.5 & 60 & 1 & $M=0.91 \mathrm{yr}^{-1}\left(\right.$ temperature $\left.=18^{\circ} \mathrm{C}\right)(M$ equation: Pauly 1980$), F=2.61 \mathrm{yr}^{-1}$ \\
\hline 18.5 & 26 & 1 & $M=0.49 \mathrm{yr}^{-1},\left(\right.$ Djabali et al. 1994), $F=3.03 \mathrm{yr}^{-1}$ \\
\hline 19.5 & 15 & 1 & $Z=3.52 \mathrm{yr}^{-1}$ (Length-converted catch curve) (Fig. 4) \\
\hline 20.5 & 03 & 1 & \\
\hline 21.5 & 02 & 1 & Size at first maturity (Sexes combined): $L_{50}=12.3 \mathrm{~cm}$ \\
\hline 22.5 & 1 & 1 & \\
\hline
\end{tabular}

$\mathrm{ML}=$ mid-length; $\mathrm{MI}=$ mature individuals; $n=$ number of fish.

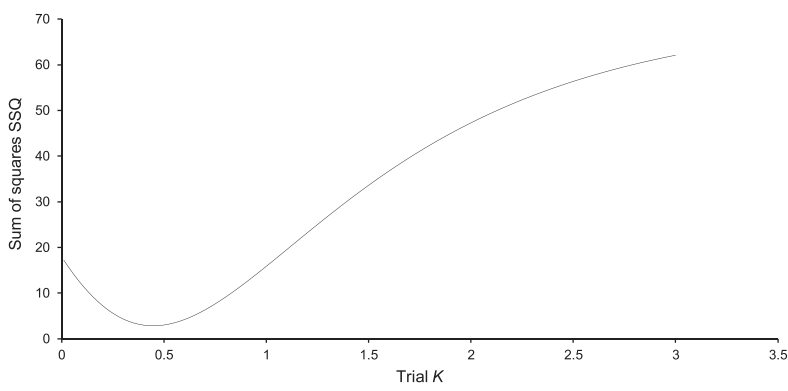

Fig. 2. $K$ optimization through minimisation of SSQ of sardine, Sardina pilchardus, in the central region of the Algerian coast (VONBIT for Excel: Stamatopoulos unpublished ${ }^{*}$ )

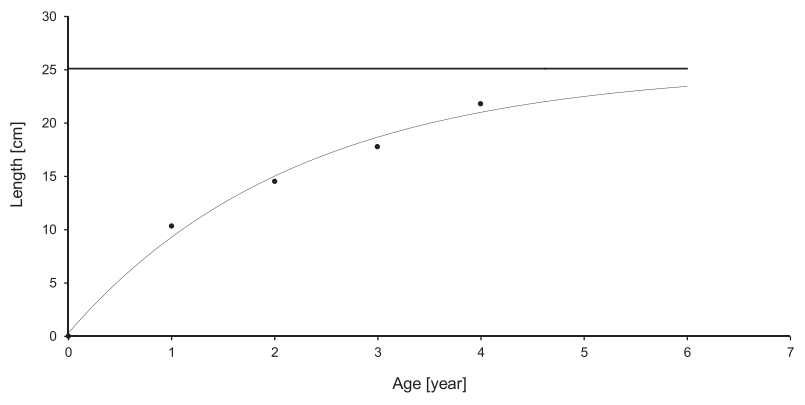

Fig. 3. Von Bertalanffy growth function of sardine, Sardina pilchardus, in the central region of the Algerian coast (VONBIT for Excel: Stamatopoulos unpublished ${ }^{*}$ ) 
$\left(F_{\mathrm{C}}\right)=1$ coincided with the maximum sustainable yield (MSY) $\left(Y_{\max } \cdot R^{-1}=6.688 \mathrm{~g}\right.$, factor of fishing mortality rate that maximizes equilibrium yield per recruit $\left(F_{\max }=0.98\right)$. It is at this effort level that the available recruitment is used at its maximum in terms of capture. As for the current biomass per recruit $\left(B_{\mathrm{C}} \cdot R^{-1}=6.060 \mathrm{~g}\right)$, which expresses the annual average biomass of survivors as a function of fishing mortality is slightly lower than the maximum balanced biomass $\left(B_{\max } \cdot R^{-1}=6.129 \mathrm{~g}\right)$. Values of yield per recruit corresponding to $F_{0.1}\left(Y_{0.1} \cdot R^{-1}\right)$ and the biomass per recruit corresponding to $F_{0.1}\left(B_{0.1} \cdot R^{-1}\right)$ were 6.103 and $9.582 \mathrm{~g}$, respectively (for $F_{0.1}=0.44$ ).

In addition, for $M=0.49 \mathrm{yr}^{-1}$ (Djabali et al. 1994), the mean biomass of the sardine was estimated at $3986.79 \mathrm{t}$, which the spawning stock biomass is $1810.39 \mathrm{t}(45.41 \%$ of the stock). The $Y_{\mathrm{C}} \cdot R^{-1}$ was estimated at $10.375 \mathrm{~g}$ for $F_{\mathrm{C}}=1$. The MSY which is of the order of $11.781 \mathrm{~g}$ for $F_{\text {Max }}=0.4$ was situated at the left of $Y_{\mathrm{C}} \cdot R^{-1} \cdot B_{\mathrm{C}} \cdot R^{-1}$ oscillated around $7.387 \mathrm{~g}$. There remains much lower than $B_{\max } \cdot R^{-1}$ evaluated at $15.538 \mathrm{~g}$. Values $Y_{0.1} \cdot R^{-1}$ and $B_{0.1} \cdot R^{-1}$ were 11.116 and $23.137 \mathrm{~g}$, respectively (for $F_{0.1}=0.23$ ) (Table 6).

\section{DISCUSSION}

Analysis of Table 3 shows that the variation of the vertebral mean in different areas within the Mediterranean is random: i.e., it does not follow any discernible pattern (Table 7). This is probably due to the fact that the presently reported study has covered individuals who hatched in very different years or periods differing in hydrological parameters. Indeed, vertebral composition can be affected by the water temperature to which eggs are subjected during the early stages of embryonic development. In this regard, Blaxter (1958) man-

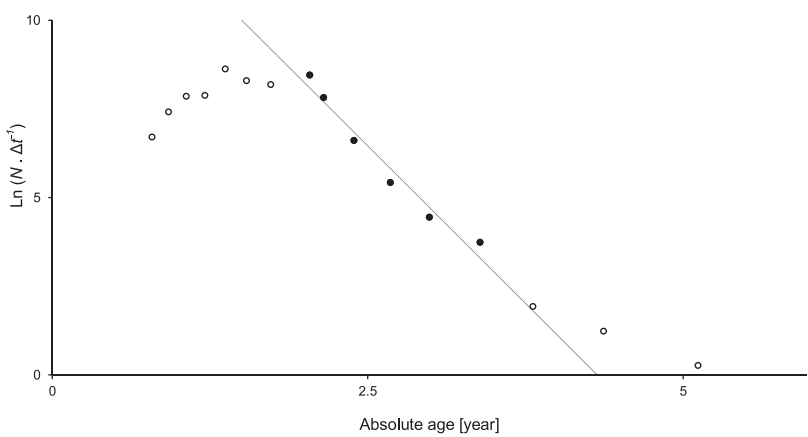

Fig. 4. Calculation of $Z$ by length-converted catch curve of sardine, Sardina pilchardus, in the central region of the Algerian coast (FISAT II 1.2.0, 2005); $Z=3.52 \mathrm{yr}^{-1} ; r^{2}$ $=0.979, L_{\infty}=25.12 \mathrm{~cm}, K=0.45, t_{0}=-0.028$ Year; $n$ is the number of fish in length class $i$; $\Delta t$ is the time needed for the fish $t_{\mathrm{o}}$ grow through length class $i, t$ is the age (or the relative age, computed with $t_{0}=0$ ) corresponding to the midlength of class $i$; dark circles in the figure represent the points used in calculating $(Z)$; blank observations are excluded from the linearized regression curve of catches (These are the first size classes that form the ascending part of the curve, these fish are not yet fully recruited to the fishery; larger size classes are also excluded for their low numbers of samples)

Table 5

Captures in numbers and weights according to size, obtained by VIT 1.2 of sardine, Sardina pilchardus, in the central region of the Algerian coast

\begin{tabular}{|c|c|c|c|c|}
\hline \multirow[b]{2}{*}{ Class $[\mathrm{cm}]$} & \multicolumn{2}{|c|}{$M=0.91 \mathrm{yr}^{-1}$ (Pauly 1980) } & \multicolumn{2}{|c|}{$M=0.49 \mathrm{yr}^{-1}$ (Djabali et al. 1994) } \\
\hline & Catch number & Catch weight $[\mathrm{g}]$ & Catch number & Catch weight $[\mathrm{g}]$ \\
\hline 7.5 & 6223705.73 & 19981540.69 & 6622560.42 & 20010570.11 \\
\hline 8.5 & 14458196.37 & 63518261.48 & 14455696.39 & 63595110.15 \\
\hline 9.5 & 23645917.22 & 145086585.63 & 23641828.58 & 145232289.46 \\
\hline 10.5 & 25853819.13 & 214327520.46 & 25849348.72 & 214532279.15 \\
\hline 11.5 & 58331343.99 & 634540018.78 & 58321257.85 & 634817529.87 \\
\hline 12.5 & 45938604.24 & 642298613.9 & 45930660.94 & 642663326.81 \\
\hline 13.5 & 44158038.19 & 777656007.52 & 44150402.77 & 778093174.15 \\
\hline 14.5 & 64100378.01 & 1391961494.61 & 64089294.34 & 1391670102.16 \\
\hline 15.5 & 37106996.61 & 982443076.98 & 37100580.39 & 981636673.16 \\
\hline 16.5 & 12321517.11 & 394744095.72 & 12319386.58 & 394433427.1 \\
\hline 17.5 & 4273358.53 & 163808560.45 & 4272619.62 & 163737128.32 \\
\hline 18.5 & 1851788.7 & 83958154.56 & 1851468.5 & 83941895.83 \\
\hline 19.5 & 1068339.63 & 56605844.83 & 1068154.91 & 56548622.75 \\
\hline 20.5 & 213667.93 & 13216039.81 & 213630.98 & 13225501.85 \\
\hline 21.5 & 142445.28 & 10130242.59 & 142420.65 & 10139416.87 \\
\hline 22.5 & 71222.64 & 5723941.99 & 71210.33 & 5722952.26 \\
\hline Total & 340159339.33 & 5600000000 & 340100521.97 & 5600000000 \\
\hline Mean age [yr] & & & & \\
\hline Mean length $[\mathrm{cm}]$ & & & & \\
\hline
\end{tabular}


aged to experimentally modify the vertebral mean of herring's, Clupea harengus Linnaeus, 1758, embryos, by varying the water temperature during the first days of embryonic development. Ben-Tuvia (1963) observed that the vertebral mean of successive cohorts of immature round sardinella, Sardinella aurita Valenciennes, 1847, caught off Israel, fell from 47.905 in June to 47.433 in October. The correlation between the vertebral mean and the mean sea surface temperature was significant: a difference of $10^{\circ} \mathrm{C}$ between the coldest month spawning season (April) and the warmest month (August), resulted in a difference of 0.472 of vertebral mean.

Following these results, we can conclude that the population of sardine, Sardina pilchardus, of Algerian coast seems to be represented by three stocks:

- the first - specific to the western region up to Arzew,

- the second-stretching from Tenes to Bejaia (central region), and

- the last-specific to the eastern region of the Algerian coasts eastwards from Jijel (Fig. 1).

This observation, which is essential in the study of stock's exploitation, should be confirmed by a genetic study of sets comprising at least 60 individuals from various fishing harbours.

Concerning the calculation of linear growth parameters, we initially fed the age-length key recorded in Table 3 into the FISHPARM 3.0 T (Sailla et al. 1988) and New VONBIT for Excel. This is the origin of aberrant results such as: $\left(L_{\infty}=204.61 \mathrm{~cm}, K=0.02 \mathrm{yr}^{-1}\right)$ for the New VONBIT for Excel and $\left(L_{\infty}=151.61 \mathrm{~cm}, K=0.028 \mathrm{yr}^{-1}\right)$ for the FISHPARM 3.0 T. This incongruous result is probably due to the irregular rate of increase (Table 3). Indeed, if the growth rate increased, instead of decreasing with the last age, then the $L_{\infty}$ increased to reach aberrant values. However, $K$ decreased to approach zero. To remedy this problem, the introduction of the pair of values (age $=0, \mathrm{TL}=0$ ) in the FISHPARM 3.0 T and the New VONBIT for Excel was essential for coherent results (Table 4). However, this problem does not arise for the FISAT II 1. 2.0 (Gayanilo et al. 2005) because the software itself systematically incorporates the values (age $=0$, $\mathrm{TL}=0$ ) in the calculation of the parameters $L_{\infty}, K$, and $t_{0}$.

It is very difficult to make a comparison between our results and those obtained by other authors in the

Yield and biomass parameters obtained by the VIT 1.2, according to the length of sardine,

Table 6 Sardina pilchardus, in the central region of the Algerian coast

\begin{tabular}{|c|c|c|c|c|c|c|c|c|c|}
\hline \multicolumn{5}{|c|}{ Parameters for $M=0.91 \mathrm{yr}^{-1}$} & \multicolumn{5}{|c|}{ Parameters for $M=0.49 \mathrm{yr}^{-1}$} \\
\hline Factor & $F$ & $\begin{array}{l}Y / R \\
{[\mathrm{~g}]}\end{array}$ & $\begin{array}{l}B / R \\
{[\mathrm{~g}]}\end{array}$ & $\begin{array}{c}\text { SSB } \\
{[\mathrm{g}]}\end{array}$ & Factor & $F$ & $\begin{array}{l}Y / R \\
{[\mathrm{~g}]}\end{array}$ & $\begin{array}{l}B / R \\
{[\mathrm{~g}]}\end{array}$ & $\begin{array}{c}\text { SSB } \\
{[\mathrm{g}]}\end{array}$ \\
\hline$F_{0}=0$ & 0 & 0 & 21.92 & 17.684 & $F_{0}=0$ & 0 & 0 & 55.47 & 50.02 \\
\hline$F_{0.1}=0.44$ & 1.15 & 6.103 & 9.58 & 5.754 & $F_{0.1}=0.23$ & 0.70 & 11.116 & 23.137 & 18.132 \\
\hline$F_{\mathrm{MSY}}=0.98$ & 2.56 & 6.688 & 6.12 & 2.672 & $F_{\mathrm{MSY}}=0.4$ & 1.21 & 11.781 & 15.538 & 10.784 \\
\hline$F_{\mathrm{C}}=1$ & 2.61 & 6.688 & 6.06 & 2.615 & $F_{\mathrm{C}}=1$ & 3.03 & 10.375 & 7.387 & 3.354 \\
\hline \multicolumn{5}{|c|}{ Number of recruits: 837293142.21} & \multicolumn{5}{|c|}{ Number of recruits: 539734212.89} \\
\hline \multicolumn{5}{|c|}{ Parameters for $M=0.91 \mathrm{yr}^{-1}$} & \multicolumn{5}{|c|}{ Parameters for $M=0.49 \mathrm{yr}^{-1}$} \\
\hline Factor & $Y[\mathrm{t}]$ & & {$[\mathrm{t}]$} & $\mathrm{SSB}[\mathrm{t}]$ & Factor & $Y[\mathrm{t}]$ & & {$[\mathrm{t}]$} & $\mathrm{SSB}[\mathrm{t}]$ \\
\hline$F_{0}=0$ & 0 & & 0.16 & 14806.7 & $F_{0}=0$ & 0 & & & 26997.5 \\
\hline$F_{0.1}=0.44$ & 5110 & & & 4817.8 & $F_{0.1}=0.23$ & 5999.7 & & 87.8 & 9786.4 \\
\hline$F_{\mathrm{MSY}}=0.98$ & 5600 & & & 2.672 & $F_{\mathrm{MSY}}=0.4$ & 6358.6 & & 86.4 & 5820.5 \\
\hline$F_{\mathrm{C}}=1$ & 5600 & & & 2237.2 & $F_{\mathrm{C}}=1$ & 5600 & & 87 & 1810.3 \\
\hline
\end{tabular}

$M=0.91 \mathrm{yr}^{-1}$ according to Pauly (1980), $M=0.49 \mathrm{yr}^{-1}$ according to Djabali et al. (1994); $F=$ fishing mortality, $Y / R=$ yield per recruit, $B / R=$ biomass per recruit, $\mathrm{SSB}=$ spawning stock biomass, $Y=$ total yield, $B=$ total biomass, $F_{0}=$ factor of no fishing, $F_{0.1}=$ factor of fishing mortality rate at which the marginal yield-per-recruit is only 10 percent of the marginal yieldper-recruit on the unexploited stock, $F_{\mathrm{MSY}}=$ factor of fishing mortality rate that maximizes equilibrium yield per recruit, $F_{\mathrm{C}}$ $=$ factor of current effort fishing.

Table 7

The vertebral mean of sardine, Sardina pilchardus, obtained in the Mediterranean Sea

\begin{tabular}{llc}
\hline Author & Region & Mean vertebral \\
\hline Lee (1961) & Sète (France) & 51.64 \\
Fréon and Stéquert (1979) & Mediterranean Sea & $50.5-51.4$ \\
Bouchereau (1981) & Oran (Algeria) & 51.29 \\
Kartas (1981) & Tunisia & 51.57 \\
Mustać and Sinovčić (2010) & Zadar (Croatia) & $50.02 \pm 0.97$ \\
\hline
\end{tabular}


Mediterranean (Table 8) because the approach used for age determination (scalinometry, otholitometry, and indirect methods) differs from one author to the other. Our $L_{\infty}$ remained higher than those found by other researchers in the Mediterranean. This is due, no doubt, to the presence of sardine of large sizes up to $22.9 \mathrm{~cm}$ TL in our sample which are included in the calculation of the age-length key. It is interesting to note that it is in the central region of the Algerian coast, that the largest sardine $\left(L_{\mathrm{Max}}=20 \mathrm{~cm}\right)$ was sampled by Mouhoub (unpublished*) and Brahmi et al. (1998). The high value of $K\left(0.45 \mathrm{yr}^{-1}\right)$ corresponds to the theory of Sparre and Venema (1996), which concluded that small pelagic fish such as sardines are characterized by rapid growth so implying a high value of $K$ and a low longevity.

The selection of appropriate growth parameters for the development of the assessment is important (Anonymous 2012b). To do this, we calculated the performance index growth which is of the order of 2.45. This value is very close to that of $\varnothing^{\prime}$ provided by FishBase (Froese and Pauly 2014) (2.57). This allows us to conclude that the parameters of growth obtained in this study are accurate.

Regarding the study of the length-weight relation, the $t$-test based on the comparison of two slopes provided a value (0.097) less than 1.96 for $\alpha=5 \%\left(r^{2}=0.99\right)$. This result allows us to conclude that sardine of both sexes, captured in the study area, was characterized by an isometric growth.

Pauly and Serrano (1986), Silvestre et al. (1991), and Bouaziz (2006) noted that in small pelagics, the values of fishing mortality $(F)$ that maximize the yield per recruit are generally very high. This agrees perfectly with the value of $Z$ chosen, which was $3.52 \mathrm{yr}^{-1}\left(r^{2}=0.979\right)$.

The value of $M$ estimated by the empirical equation of Pauly (1980) was $0.91 \mathrm{yr}^{-1}$, on the other hand that obtained by the equation of Djabali et al. (1994), was lower by 53.8 percentage points $\left(0.49 \mathrm{yr}^{-1}\right)$. Indeed, in warm waters, fish are more likely to meet a hungry predator rather than satiated one because all tropical fish feed more than those living in temperate regions such as the Mediterranean, to satisfy higher metabolic needs. This would result in higher mortality among prey fish (Winberg 1960 cited by Pauly 1997). This hypothesis seems the most likely especially because polar fish, which have a very important metabolism, also have unusually high natural mortality (Wohlschlab 1960, 1964 cited by Pauly 1997).

In addition, it is interesting to note that the result obtained by the method of Djabali et al. (1994) approaches the instantaneous rate of natural mortality of sardine $\left(M=0.38 \mathrm{yr}^{-1}\right)$ which is part of the 175 reliable values of $M$ mentioned by FishBase (Froese and Pauly 1996).

The analysis of the VPA by the VIT 1.2, shows that the increase of the natural mortality from $0.49 \mathrm{yr}^{-1}$ (Djabali et al. 1994) to $0.91 \mathrm{yr}^{-1}$ (Pauly 1980) had no effect on the average size of the stock and the average size of capture that oscillated around 10.5 and $12.8 \mathrm{~cm}$. However, the critical size of the virgin stock increased when natural mortality decreased. In fact, it increases from $14 \mathrm{~cm}$ for $M=0.91 \mathrm{yr}^{-1}$ (Pauly, 1980) to $18 \mathrm{~cm}$ for $M=0.49 \mathrm{yr}^{-1}$ (Djabali et al. 1994) (Table 5).

The management of the fishery of small pelagic species, based only on a single value of $M$ for the assessment of the yield and the biomass per recruit, can be misleading. Based on the recommendations of Froese and Proelss (2012) (Table 9), we noticed that due to variation in natural mortality from $0.91 \mathrm{yr}^{-1}$ Pauly (1980) to $0.49 \mathrm{yr}^{-1}$ Djabali et al. (1994), the sardine stock in the central region of the Algerian coast changed from a state of not overfished and not overfishing to a state of overfished and overfishing (Table 9).

Growth parameters of sardine, Sardina pilchardus, obtained in the Mediterranean Sea

Table 8

\begin{tabular}{llcc}
\hline Author & Region & $L_{\infty}[\mathrm{cm}]$ & $\begin{array}{c}K \\
{\left[\mathrm{yr}^{-1}\right]}\end{array}$ \\
\hline Larrañeta (1975) & Alicante & 22.4 & 0.29 \\
Sinovčić (1983) & Central Adriatic & 20.5 & 0.46 \\
Mouhoub (1986) ${ }^{1 *}$ & Algiers & 20.3 & 0.26 \\
Bouchereau and Ghazi (1988) & Beni-Saf (Algeria) & 19.9 & 0.19 \\
Bouchereau and Ghazi (1988) & Beni-Saf (Algeria) & 17.6 & 0.26 \\
Djabali et al. (1990) & Beni-Saf (Algeria) & 20.5 & 0.26 \\
Djabali et al. (1990) & Beni-Saf (Algeria) & 19.2 & 0.28 \\
Campillo (1992) & Gulf of Lion & 20.4 & 0.31 \\
Alemany and Alvarez (1993) & Western Mediterranean & 19.9 & 0.93 \\
Brahmi et al. (1998) & Algiers & 22.6 & 0.26 \\
Brahmi et al. (1998) & Algiers & 18.9 & 0.46 \\
Voulgaridou and Stergiou (2003) & Eastern Mediterranean & 20.8 & 0.86 \\
\hline
\end{tabular}

Based on total length; $L_{\infty}=$ asymptotic length, $K=$ curvature parameter of the von Bertalanffy growth function.

\footnotetext{
${ }^{*}$ Mouhoub R. 1986. Contribution à l'étude de la dynamique de la population exploitée de la sardine (Sardina pilchardus, Walbaum, 1792) des côtes algéroises. Thèse de Magister. USTHB, Alger.
} 
Based on the principles of the precautionary approach, we recommend that managers who are not interested in the yield per recruit and biomass per recruit, but in the total yield and biomass (Table 6), to adjust for $M=0.91$ $\mathrm{yr}^{-1}$ (Pauly 1980), the current production $Y_{C}(5600 \mathrm{t})$ to $Y_{0.1}\left(5110\right.$ t). To do this, simply reduce $F_{\mathrm{C}}$ to $F_{0.1}$ which is of the order of 0.44 and represents a decrease of 56 percentage points. According to Cadima (2002), $F_{0.1}$ is the value of $F$ corresponding to the capture of $10 \%$ of the virgin biomass. However, this would increase the biomass in the sea from 5074 to $8022.9 \mathrm{t}$ and the spawning stock biomass from 2237.2 to $4817.8 \mathrm{t}$. Note also that in the case of an absence of fishing mortality, the exploitable biomass
$\left(B_{0}\right)$ of the sardine would reach $18360.16 \mathrm{t}$ in which the spawning stock biomass represents 14806.7 t. According to Caddy (1994), the virgin stock is considered as a Biological Reference Point (BRP) and corresponds to the average long-term expected biomass in the absence of fishing mortality (Fig. 5).

Moreover, to achieve the $Y_{0.1}$ for $M=0.49 \mathrm{yr}^{-1}$ (Djabali et al. 1994), it would be advisable to adjust $F_{\mathrm{C}}$ to $F_{0.1}$ estimated at 0.23 and represents a decrease of 77 percentage points. This would increase the long-term production from 5600 to $5999.7 \mathrm{t}$, the exploitable biomass from 3987 to $12487.8 \mathrm{t}$, and the spawning stock biomass from 1810.3 to 9786.4 t (Fig. 6).

Table 9

Criteria used for assigning traffic-light colours to overall stock status, biomass, and fishing pressure

\begin{tabular}{cllc}
\hline & Assessment & Status & Biomass and fishing pressure \\
\hline FP & Light grey & Not overfished and not overfishing & $B \geq 0.9 B_{\mathrm{MSY}}$ and $F \leq 1.1 F_{\text {MSY }}$ \\
& Grey & Overfished or overfishing & $B<0.9 B_{\mathrm{MSY}}$ or $F>1.1 F_{\mathrm{MSY}}$ \\
& Dark grey & Overfished and overfishing & $B<0.9 B_{\mathrm{MSY}}$ and $F>1.1 F_{\mathrm{MSY}}$ \\
P91 & Light grey & Not overfished and not overfishing & $B \geq 0.9 B_{\mathrm{MSY}}$ and $F \leq 1.1 F_{\mathrm{MSY}}$ \\
D49 & Dark grey & Overfished and overfishing & $B<0.9 B_{\mathrm{MSY}}$ and $F>1.1 F_{\mathrm{MSY}}$ \\
\hline
\end{tabular}

FP $=$ Froese and Proelss (2012), P91 = status of sardine, Sardina pilchardus, along the central Algerian coast for $M=0.91$ $\mathrm{yr}^{-1}$ (Pauly 1980), D49 = status of sardine, Sardina pilchardus, along the central Algerian coast for $M=0.49 \mathrm{yr}^{-1}(\mathrm{Djabali}$ et al. 1994); $B_{\mathrm{MSY}}=$ total biomass that maximizes equilibrium yield per recruit, $F=$ fishing mortality, $F_{M S Y}=$ fishing mortality rate that maximizes equilibrium yield per recruit.

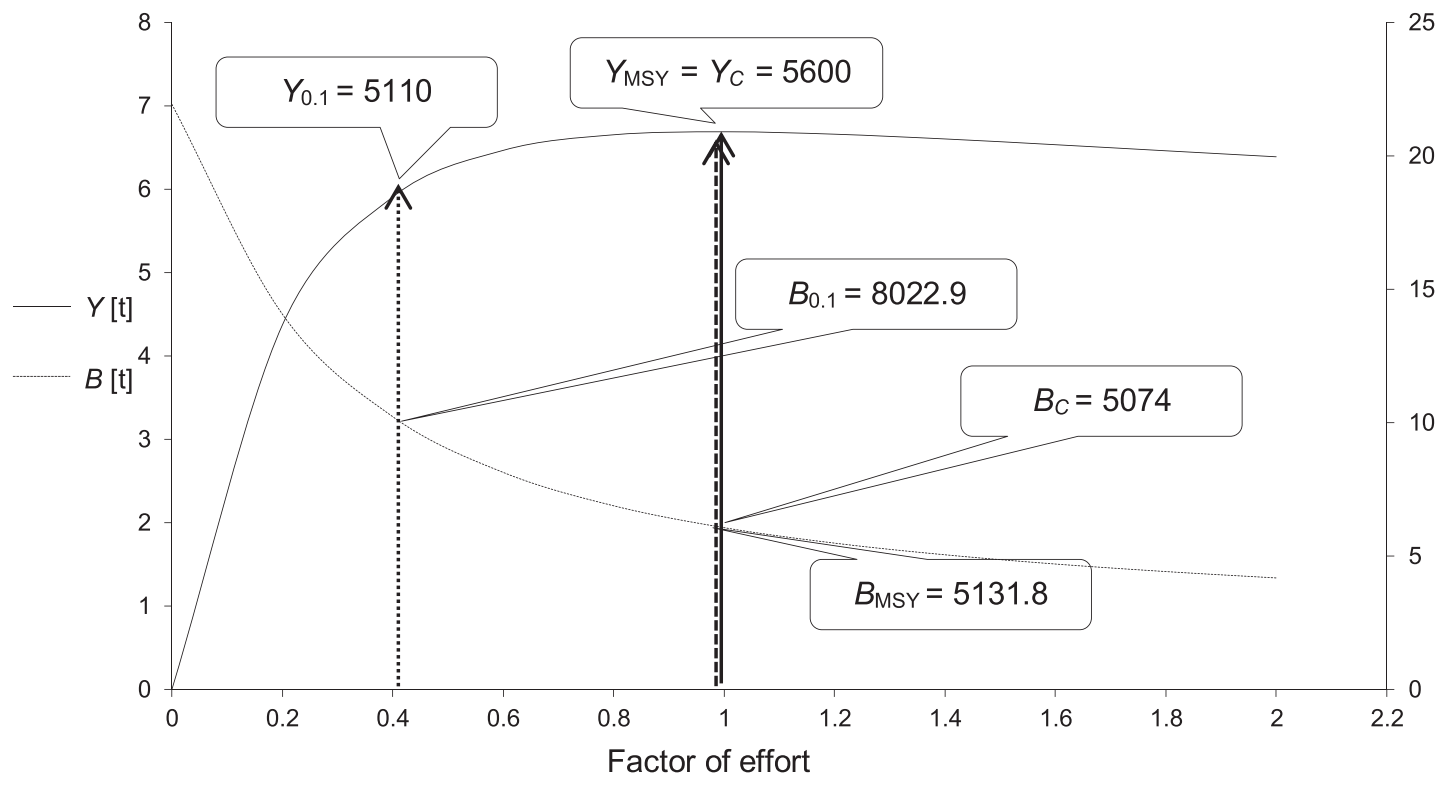

Fig. 5. Total yield $(Y)$ and total biomass $(B)$, of sardine, Sardina pilchardus, in the central region of the Algerian coast; $M=0.91 \mathrm{yr}^{-1}, M$ equation of Pauly's (1980); $Y_{0.1}=$ total yield corresponding to the factor of fishing mortality rate at which the marginal yield-per-recruit is only $10 \%$ of the marginal yield-per-recruit on the unexploited stock, $Y_{\mathrm{MSY}}=$ total yield corresponding to the factor of fishing mortality rate that maximizes equilibrium yield per recruit, $Y_{\mathrm{C}}=$ current total yield corresponding to the factor of current effort fishing, $B_{0.1}=$ total biomass corresponding to the factor of fishing mortality rate at which the marginal yield-per-recruit is only $10 \%$ of the marginal yield-perrecruit on the unexploited stock, $B_{\mathrm{C}}=$ current total biomass corresponding to the factor of current effort fishing, $B_{\mathrm{MSY}}=$ total biomass corresponding to the factor of fishing mortality rate that maximizes equilibrium yield per recruit, $Y_{\mathrm{C}}=$ total current yield corresponding to the factor of current effort fishing 


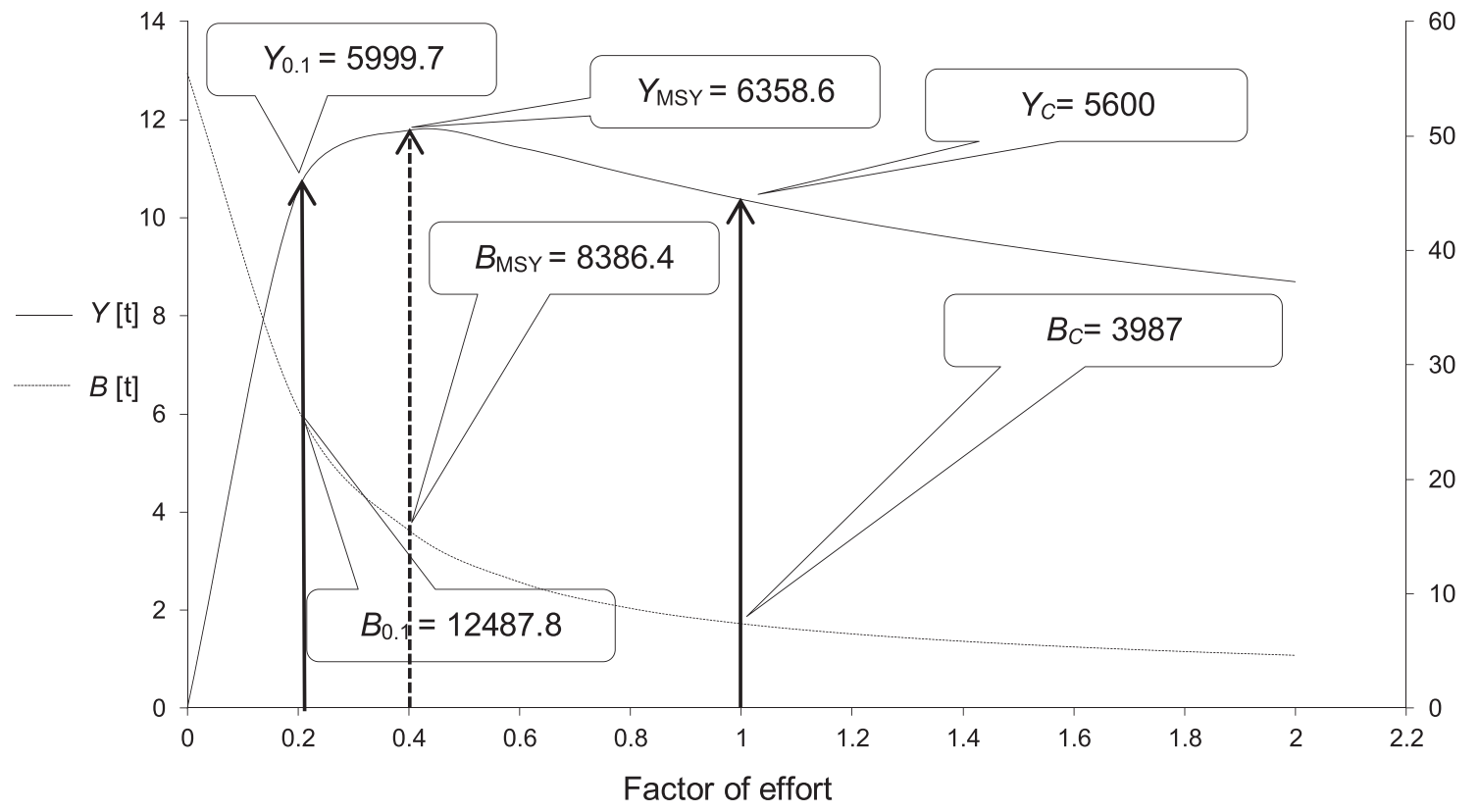

Fig. 6. Total yield $(Y)$ and total biomass $(B)$, of sardine, Sardina pilchardus, in the central region of the Algerian coast; $M=0.49 \mathrm{yr}^{-1}, M$ equation of Djabali et al. (1994); $Y_{0.1}=$ total yield corresponding to the factor of fishing mortality rate at which the marginal yield-per-recruit is only $10 \%$ of the marginal yield-per-recruit on the unexploited stock, $Y_{\mathrm{MSY}}=$ total yield corresponding to the factor of fishing mortality rate that maximizes equilibrium yield per recruit, $Y_{\mathrm{C}}=$ current total yield corresponding to the factor of current effort fishing, $B_{0.1}=$ total biomass corresponding to the factor of fishing mortality rate at which the marginal yield-per-recruit is only $10 \%$ of the marginal yieldper-recruit on the unexploited stock, $B_{\mathrm{C}}=$ current total biomass corresponding to the factor of current effort fishing, $B_{\mathrm{MSY}}=$ total biomass corresponding to the factor of fishing mortality rate that maximizes equilibrium yield per recruit, $Y_{\mathrm{C}}=$ total current yield corresponding to the factor of current effort fishing

\section{CONCLUSION}

The fall in the value of natural mortality resulting from applying two different approaches, namely those of Pauly (1980) and Djabali et al. (1994), creates two scenarios that are contradictory, suggesting the state of not overfishing and not overfished (light grey) versus the state of overfishing and overfished (dark grey), respectively. The choice between these scenarios, from which, it is important to advise and guide the management and the planning of fisheries, focuses on the case of overfishing and overfished. This choice is motivated by the geographical origin of biological material used for the development of the equation of natural mortality. Indeed, for Djabali et al. (1994), the estimate of $M$ was compiled for 24 species of Mediterranean teleosts, belonging to 56 stocks (with the two sexes of the same population counting as different stocks where sufficient data were available). However, Pauly's original model (1980), while based on 175 stocks from polar to tropical areas, included only five Mediterranean data sets. The Mediterranean environment has its own characteristics, and the wide use of Pauly's equation in this region may thus lead to errors.

The implementation of this recommendation would allow the maximum sustainable yield in the long-term, whilst ensuring the renewal of the exploitable stock of sardine in the central region of the Algerian coast.

\section{REFERENCES}

Abella A., Auteri R., Serena F. 1995. Some aspects of growth and recruitment of hake in the northern Tyrrhenian Sea. [Rapport de la première réunion du groupe de travail DYNPOP du CIESM, Tunis.] Cahiers Options Méditerranéennes No. 10: 27-28.

Aldebert Y., Recasens L. 1995. Estimation de la croissance du merlu dans le golfe du Lion par analyse des fréquences de tailles. [Rapport de la première réunion du groupe de travail DYNPOP du CIESM, Tunis.] Cahiers Options Méditerranéennes No. 10: 49-50.

Alemany F., Álvarez F. 1993. Growth differences among sardine (Sardina pilchardus, Walb.) populations in western Mediterranean. Scientia Marina 57 (2-3): 229-234.

Alemany F., Oliver P. 1995. Growth of hake in the Balearic Sea: a proposal of new growth model with higher growth rates. [Rapport de la première réunion du groupe de travail DYNPOP du CIESM, Tunis.] Cahiers Options Méditerranéennes No. 10: 51-52.

Anonymous 1996. L'approche de précaution appliquée aux pêches de capture et aux introductions d'espèces. Élaboré par la consultation technique sur l'approche de précaution appliquée aux pêches de capture. Lysekil (Suède), 6-13 juin 1995. FAO, Directives techniques pour une pêche responsable No. 2. FAO, Rome, Italy, 
Anonymous 2006. Manuel statistiques des pêches 2000-2005. Ministère de la Pêche et des Ressources Halieutiques/SousDirection des Statistiques.

Anonymous 2009. Report of the FAO Working Group on the Assessment of Small Pelagic Fish off Northwest Africa. Nouakchott, Mauritania, 21-30 April 2009. FAO Fisheries and Aquaculture Report No. 965.

Anonymous 2012a. Manuel statistiques des pêches 2010-2011. Ministère de la Pêche et des Ressources Halieutiques/SousDirection des Statistiques.

Anonymous 2012b. Report of the Working Group on Stock Assessment of Demersal Species Chania (Crete), Greece, 24-29 October 2011. General Fisheries Commission For The Mediterranean. GFCM:SAC14/2012/Inf.12.

Blaxter J.H.S. 1958. The racial problem in herring from the viewpoint of recent physiological, evolutionary and genetical theory. Rapports et procès-verbaux des réunions /Conseil permanent international pour l'exploration de la mer 143 (2): $10-19$.

Ben-Tuvia A. 1963. Influence of temperature on the vertebral number of Sardinella aurita from the eastern Mediterranean. Israel Journal of Zoology 12 (1-4): 59-66.

Bouaziz A. 2006. Estimation du point de référence biologique, $\mathrm{F}_{0 \cdot 1}$, de Sardinella aurita de la région centre de la côte algérienne. Bulletin de la Société Zoologique de France 131 (2): 97-106.

Bouaziz A., Semroud R., Brahmi B., Cheniti S. 1998. Estimation de la croissance de la sardinelle (Sardinella aurita Valenciennes, 1847) dans la région algéroise par analyse des fréquences de tailles. Cahiers Options Méditerranéennes No. 35: 43-49.

Bouaziz A. 2007. La sardinelle (Sardinella aurita Valenciennes, 1847) des côtes algériennes: distribution, biologie et estimation des biomasses. Thèse de Doctorat d'État. Université USTHB, Alger.

Bouchereau J.L. 1981. Contribution à l'étude de la biologie et de la dynamique de la population exploitée de Sardina pilchardus (Walbaum, 1792) dans la baie d'Oran (Algérie). Thèse de Doctorat $3^{\text {ème }}$ cycle. Université d'Aix-Marseille II.

Bouchereau J.L., Ghazi M. 1988. Paramètres de croissance de (Sardina pilchardus, Walbaum, 1792), de la baie de BeniSaf (Algérie). Rapport de la Commission Internationale de la Mer Méditerranée 31 (2): 267.

Brahmi B., Bennoui A., Oualiken A. 1998. Estimation de la croissance de la sardine (Sardina pilchardus Walbaum, 1792) dans la région centre de la côte algérienne. Cahiers Options Méditerranéennes No. 35: 57-64.

Caddy J.F. 1994. Checks and balances in the management of marine fish stocks: organizational requirements for a limited reference point approach. ICES Statutory Meeting document CM 1994/T 1: 1-18.

Caddy J.F. 2009. Practical issues in choosing a framework for resource assessment and management of Mediterranean and Black Sea fisheries. Mediterranean Marine Science 10 (1): 83-119.

Cadima E.L. 2002. Manuel d'évaluation des ressources halieutiques. FAO document technique sur les pêches 393. FAO, Rome, Italy.
Campana S.E. 2001. Accuracy, precision and quality control in age determination, including a review of the use and abuse of age validation methods. Journal of Fish Biology 59 (2): 197-242. DOI: $10.1006 /$ jfbi.2001.1668

Campillo A. 1992. Les pêcheries françaises de Méditerranée: synthèse des connaissances. Institut Français de Recherche pour l'Exploitation de la Mer, France.

Djabali F., Boudraa S., Bouhdid A., Bousbia H., Bouchelaghem E.H., Brahmi B., Dob M., Derdiche O., Djekrir F., Kadri L., Mammasse M., Stambouli A., Tehami B. 1990. Travaux réalisés sur les stocks pélagiques et demersaux de la région de Béni-saf. FAO Fisheries Report No. 447: 160-165.

Djabali F., Mehailia A., Koudil M., Brahmi B. 1994. A reassessment of equations for predicting natural mortality in Mediterranean teleosts. Naga, the ICLARM Quarterly 17 (1): 33-34.

Fréon P., Stéquert B. 1979. Notes sur la présence de Sardina pilchardus (Walb.) au Senegal : Etude de la biométrie et interprétation. Cybium 3 (6): 65-90.

Froese R., Pauly D. 1996. FishBase 96: design and data sources. ICLARM, Manila, 1-179.

Froese R., Pauly D. (eds.) 2014. FishBase. [version 02/2014] http://www.fishbase.org.

Froese R., Proelss A. 2012. Evaluation and legal assessment of certified seafood. Marine Policy 36 (6): 1284-1289. DOI: 10.1016/j.marpol.2012.03.017

Froese R., Tsikliras A.C., Stergiou K. 2011. Editorial note on weight-length relations of fishes. Acta Ichtyologica et Piscatoria 41 (4): 261-263. DOI: 10.3750/AIP2011.41.4.01

Gayanilo F.C.jr., Sparre P., Pauly D. 2005. FAO-ICLARM stock assessment tools II (FiSAT II). Revised version. User's guide. FAO Computerized Information Series (Fisheries). No. 8, Revised version. FAO, Rome.

Kartas F. 1981. Les clupéidés de Tunisie. Caractéristiques biométriques et biologiques. Etude comparée des populations de l'Atlantique et de la Méditerranée. Thèse de Doctorat d'Etat, Université de Tunis, Faculté des sciences.

Kirkegaard E., Rätz H.J., Cheilari A. (Eds.) 2008. Scientific, Technical and Economic Committee for Fisheries (STECF) Report of the SGMED-08-01 Working Group on the Mediterranean Part I. JRC Scientific and Technical Reports. EUR 23666 EN. Office for Official Publications of the European Communities, Luxembourg. DOI: 10.2788/56165

Larrañeta M.G. 1975. La Pesqueria pelagica de las Costas de Alicante. Investigacion Pesqueria 39 (1): 79-117.

Lee J.Y. 1961. La sardine du golfe du Lion (Sardina pilchardus sardina Regan). Revue des Travaux de l'Institut des Pêches Maritimes 25 (4): 417-512.

Mustać B., Sinovčić C. 2010. Morphometric and meristic parameters of sardine (Sardina pilchardus, Walbaum, 1792) in the Zadar fishing area. Ribarstvo 68 (1): 27-43.

Pauly D. 1980 . On the interrelationships between natural mortality, growth parameters, and mean environmental temperature in 175 fish stocks. Journal du Conseil International pour l'Exploration de la Mer 39 (3): 175-192.

Pauly D. 1984. Fish population dynamics in tropical waters: a manual for use with programmable calculators. ICLARM Studies and Reviews 8: 1-325. 
Pauly D. 1990. Length-converted catch curves and the seasonal growth of fishes. Fishbyte 8 (3): 33-38.

Pauly D. 1997. Méthodes pour l'évaluation des ressources halieutiques. Cépaduès-Éditions, Toulouse, France.

Pauly D., Munro J.L. 1984. Once more on the comparison of growth in fish and invertebrates. Fishbyte 2 (1): 21-32.

Pauly D., Serrano M. 1986. Some practical extensions to Beverton and Holt's relative yield-per-recruit model. Pp. 491-495. In: Maclean J.L., Dizon L.B., Hosillos L.V. (eds.) The First Asian Fisheries Forum. Proceedings of the First Asian Fisheries Forum, 26-31 May 1986, Manila, Philippines.

Rätz H.-J., Cheilari A., Lleonart J. 2010. On the performance of fish stock parameters derived from VIT pseudo-cohort analysis. Scientia Marina 74 (1): 155-162. DOI: 10.3989/scimar.2010.74n1155

Saila G.B., Recksiek C.W., Prager M.H. 1988. Basic Fishery Science Programs. A Compendium of Microcomputer Programs and Manual of Operations. Book series: Developments in Aquaculture and Fisheries Science Vol. 18. Elsevier, Amsterdam:
Silvestre G.T., Soriano M., Pauly D. 1991. Sigmoid selection and the Beverton and Holt equation. Asian Fisheries Science 4 (1): 85-95.

Sinovčić G. 1983. Summary of biological parameters of sardine (Sardina pilchardus, Walb.) from the central Adriatic. Pp. 147-148. In: Report of the third technical consultation on stock assessment in the Adriatic, 5-10 June 1983 Fano, Italy. FAO Fisheries Report No. 290.

Sparre P., Venema S.C. 1996. Introduction to tropical fish stock assessment, Part 1: Manual, FAO Fisheries Technical Paper 306/1.

Voulgaridou P., Stergiou K.I. 2003. Trends in various biological parameters of the European sardine, Sardina pilchardus (Walbaum, 1792), in the Eastern Mediterranean Sea. Scientia Marina 67 (Suppl. 1): 269-280.

Received: 12 January 2013

Accepted: 5 March 2014

Published electronically: 30 June 2014 